\title{
Professor Rubens Andrello
}

Maria do Rosario Silveira Porto

Irani Garcia Xavier Fontanetti

Faculdade de Educação - Universidade de São Paulo
Nosso relacionamento com o professor Rubens Andrello data da década de 1970, quando, respectivamente como aluna do curso de Pedagogia e funcionária do Departamento de Administração Escolar e Economia da Educação da FEUSP, ao qual ele pertencia, fomos cativadas por seu dinamismo e pelo trabalho que ele, entusiasticamente, desenvolvia no campus avançado da USP, em Marabá, cidade paraense às margens do Tocantins.

0 professor Andrello era uma pessoa com a qual a convivência era muito interessante, principalmente pelas opiniões singulares que emitia a respeito da educação e dos cursos de Licenciatura e Pedagogia, e pelas muitas histórias que contava sobre sua vida profissional e pessoal. Com vasta experiência no magistério público estadual, ocupava, na época, o cargo de diretor de escola, que acumulava com suas funções na Faculdade de Educação.

Sua inserção nesta Faculdade dera-se em meados da década de 70, quando foi convidado para coordenar, em Marabá, as atividades relativas à educação, incumbência, aliás, que ele desenvolvia com grande competência. Tendo elaborado um programa de estágios para os cursos de Licenciatura e de Pedagogia, encaminhava regularmente para essa cidade do Pará um grupo de alunos, os quais, convenientemente orientados por ele e supervisionados por sua equipe, tentavam organizar o caótico processo de escolarização de levas de população atraídas para o local pelas promessas de terras cultiváveis às margens da Transamazônica.

Eram tempos inóspitos, em que Marabá, situada na confluência dos rios Tocaiunas e Tocantins, que crescia desorganizadamente, sem saneamento básico, cercada por matas e ligada à Capital do Estado por um serviço aéreo precário, ainda era "terra de ninguém”, sujeita a enchentes periódicas e a doenças endêmicas, como a malária, que dizimava famílias inteiras de migrantes. Tudo estava por ser feito, em especial quanto aos serviços básicos de saúde e de educação.

Entretanto, mais do que um obstáculo, tais condições apresentaram-se ao professor Rubens como um desafio que ele enfrentou com determinação e competência, buscando paulatinamente formar uma equipe que o auxiliasse a concretizar um projeto de atendimento a escolas e professores de Marabá. A bem da verdade, é bom que se diga que, embora esse projeto fosse assumido oficialmente pela Universidade, se não havia, pois, obstáculos institucionais, também não contava o professor com grandes incentivos. Mesmo assim, "cavando" recursos materiais e financeiros, procurando pessoas que pudessem auxiliá-lo nessa empreitada, buscando apoios institucionais diversos, conseguiu levar a bom termo projetos muito importantes, como os de orientação para professores alfabetizadores e de formação de docentes, em Licenciatura Curta, para as disciplinas do $1^{\circ} \mathrm{e}$ $2^{\circ}$ graus.

Foi nesse projeto de formação de professores que nos envolvemos, respectivamente, como professora de um dos conteúdos específicos e como secretária do projeto. Empolgadas com as constantes informações sobre seu trabalho em Marabá, que o professor Rubens fazia questão de trazer aos alunos e colegas, quando ele nos convidou para 
participar desse projeto não hesitamos. Nessa experiência, tivemos a oportunidade de conhecer uma outra faceta da personalidade do professor Rubens: a de organizador e administrador - detalhista, severo quanto a prazos, atividades a serem desenvolvidas e resultados, profundamente responsável. Foi quando entendemos porque as atividades desenvolvidas na área da educação eram sempre elogiadas e apresentavam resultados satisfatórios.

Entretanto, quando the foi sugerido transformar essa rica experiência em tese de doutorado, só a custo e instado pelos colegas mais próximos, com destaque para sua orientadora, professora Beatriz Fétizon, ele aceitou a sugestão. Em sua modéstia, não via o valor no que fazia. Sua tese, sob o título "A FACULDADE DE EDUCAÇÃO E O CAMPUS AVANÇADO DA USP EM MARABÁ - 1971-1985 (uma experiência em assistência técnica em educação num município do médio Tocantins paraense)", apresenta, de forma clara e competente, um importante momento da história do professor Rubens e da Faculdade de Educação: mais de uma década rica de experiência e vivência em uma região desconhecida e inóspita deste país, e que só não continuou, porque a USP encerrou suas atividades nesse campus avançado; tese, aliás, que está a merecer uma divulgação mais sistemática, principalmente entre aqueles que se dedicam a projetos semelhantes.

Durante algum tempo, ainda, o professor Rubens coordenou as atividades de educação em um novo campus avançado da USP, o do
Vale do Ribeira, porém por pouco tempo, uma vez que começava a apresentar problemas de saúde, os quais foram se agravando nos anos seguintes.

Finalmente, há que se destacar a pessoa do professor Rubens não mais como profissional, mas como filho, irmão, tio... Como dissemos anteriormente, com uma vida rica de acontecimentos diversos, dotado de uma curiosidade e desejo constantes de conhecer o novo, apenas o que o detinha era a sua profunda ligação com a família. Solteiro, assumiu desde logo a responsabilidade de orientar, auxiliar e amparar seus parentes próximos, em especial sua mãe, cuja saúde precária exigiu dele anos de assistência contínua.

Infelizmente, uma série de acontecimentos desagradáveis e seguidos, como um desastre que sofreu e a perda de sua mãe, contribuiu para que os problemas de saúde se agravassem, em especial um câncer, contra o qual lutou durante quase dez anos, com a mesma coragem que demonstrara ao longo de sua vida, mas que acabou causando sua morte em fevereiro de 1999.

Certamente, o professor Rubens foi uma pessoa singular, sempre lembrado e citado por aqueles que tiveram a oportunidade de conhecê-lo e de com ele conviver, entre os quais nos encontramos. Assim, emocionadas e profundamente honradas com a oportunidade de falar um pouco sobre o professor RUBENS ANDRELLO, só nos resta agradecer a oportunidade. 